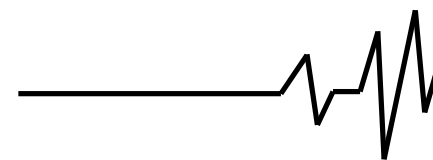

Polievoda Y.

$\mathrm{PhD}$, associate professor

Vinnytsia National Agrarian University

Полєвода Ю. А.

к.т.н., доцент

Вінницький національний аграрний університет

\title{
APPLICATION OF VIBRATION EFFECTS IN BIOFUEL PRODUCTION
}

The considered effective way of processing by-products of biofuel production. The increase in the productivity of the technological line is achieved through the introduction of new vibration equipment for the primary purification of raw glycerin.

This study proposes a new approach to determine the efficient operation of a new machine, which is useful for the purification of glycerol based on the combinatorial process of centrifugation and vibration separation. The mathematical mechanical-rheological evaluations are developed based on the experimental results.

Has been proposed to evaluate the rheological characteristics of raw glycerin purification based on the experimental testing. A compression device has been used to determine the value of the unilateral deformation of this material, which allows simulating a condition of a material at various technological modes of processing. In this study, the changes of material properties under centrifugation and vibration separation processes in a vibrocentric machine have been investigated.

At a choice of optimum technological parameters of processing of food masses by means of vibration methods of rheology are widely applied. In particular, the interaction of the working body of the machine with the treated environment.

In order to find the optimal parameters of the technological regime, the process was considered comprehensively from the standpoint of mechanics and rheology. The methods of mechanics describe the interaction of the working body with the treated environment as a mechanical object; rheology, in turn, allows you to reveal the internal processes in the environment.

The system under study can be attributed to the elasticviscous medium, which is described by a phenomenological model consisting of interconnected elastic and viscous elements.

Keywords: raw glycerin, optimal parameters, compression device, rheology, effect of vibration, biofuel, catalyst.

Analysis of last researches. At present, one of the main problems in the productive sectors of the national economy is the efficient supply of energy and saving of material resources. Therefore, the economic crisis, the state of the environment, energy security problems require the search for alternative energy sources.

Petroleum products pollute the environment and cause the release of significant amounts of carbon dioxide, which causes a greenhouse effect and, as a result, can lead to global warming. From year to year, oil fields are depleted and oil products become more expensive. Rising diesel fuel prices are leading to rising food prices, which is already a threat to the food security of the Ukrainian state. Therefore, it is important to search for and study non-traditional energy sources and the use of their by-products $[1,2]$.

Problem formulation. According to the Energy Strategy of Ukraine for the period up to 2030, according to which the demand for diesel fuel in 2010 should increase to 8 million tons. Based on this, the production of biofuels from rapeseed is planned to gradually increase. Accordingly, the yield of by-products of this production will increase - waste water and raw glycerin. 


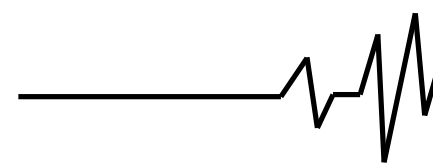

Purification of raw glycerin is a complex energy-intensive process, which consists of mechanical, physico-mechanical and physicochemical methods of processing. Therefore, it is important to search for structural and technological schemes of equipment to solve the studied process [3, 7].

Efficient processing of raw materials using vibration effects and subsequent use of glycerin will increase profitability of biodiesel production.

Presentation of the main research material. The following technologies are used in the production of biofuel:

- cyclic using catalysts with the following parameters: reaction temperature $65^{\circ} \mathrm{C}$ atmospheric pressure, time from 20 minutes to 2 hours, the amount of catalyst $1,5 \%$ by weight of oil, methyl ether yield up to $85 \%$ of the volume of biofuel;

- non-catalytic cyclic (using solvents) for parameters: reaction temperature $30^{\circ} \mathrm{C}$, atmospheric pressure, time from 5 to 10 minutes, solvent tetrahydroferan, methyl ether yield up to $98 \%$ of the volume of biofuel;

- multi-reactor continuous with process parameters: reaction temperature from 80 to $160^{\circ} \mathrm{C}$, pressure from 2 to 3 atm., Time from 6 to 10 minutes, the amount of catalyst up to $1 \%$ by weight of oil, the yield of methyl ether up to $98 \%$ from volume of biofuel.

The most efficient biofuel production technologies are cyclic with the use of catalysts and multi-reactor continuous. Non-catalytic cyclic uses expensive and aggressive solvents, requires additional equipment and highly skilled workers and is environmentally hazardous.

The choice of biofuel production technology depends on many factors: the volume of production, type and quality of raw materials, methods cleaning. For volumes of biodiesel production from 500 to 5000 tons per year, cyclic technology with the use of catalysts is preferred, in addition, it is better suited for processing lowquality raw materials. With production volumes of more than 5,000 tons per year, multi-reactor continuous technology is better suited. Given the lack of large biofuel plants in Ukraine and the low quality of raw materials, it is the cyclic scheme with a catalyst that is used (Fig. 1).

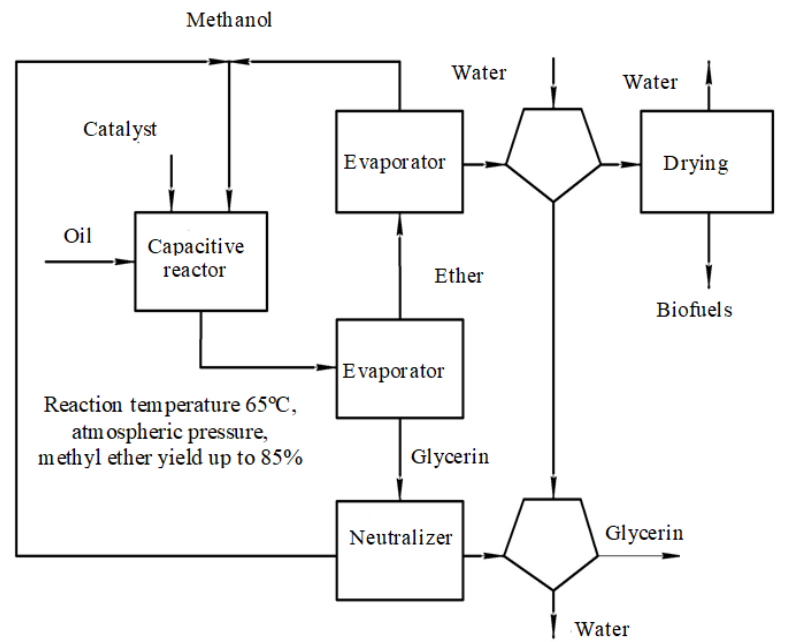

Fig. 1. Cyclic scheme of biofuel production technology (with catalyst)

To implement the primary purification of glycerol, it is proposed to use vibrating machines for purification of liquid inhomogeneous raw materials, which provides separation of raw materials by physical and mechanical properties of the material due to rotation of the perforated drum around its axis and oscillation of the container (settling tank) and removal of the fractions on the corresponding branch pipes.

The proposed designs $[4,5,8,9,10]$ implement the idea of combined interaction of vibration movement of the container and the rotational movement of the perforated drum on the process load.

Such designs of machine drive mechanisms make it possible to set the oscillation frequency of the housing and the speed of the perforated drum independently of each other, which can be used for cleaning a wide range of liquid inhomogeneous materials. As a result of the combined vibrocentric and gravitational action on parts of the product there is a significant intensification of the separation process (purification), in particular when the separation of raw glycerin, this process is 3-5 times faster than when using the actual settling. Previous studies have shown that the quality of the starting product improves to some extent - the mass fraction of pure glycerin increases to $81-83 \%$, respectively, reduces the amount of non-volatile organic residue to $2-3 \%$ [6].

Various scientific researches have been devoted to the study of the rheological behaviors of glycerol under some stress and temperature [3]. Has been presented that a linear relation between the concentration and the temperature of the mixture should be considered to model the shear stress behavior, which depends on the glycerol concentration. 


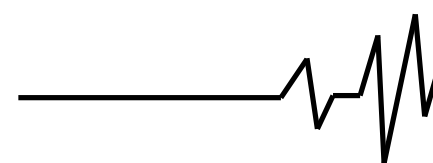

Although the influence of structural and mechanical properties of the material and the conditions of their deformation under vibration conditions is significant, it is also worth paying attention to the previous technology of material processing. Thus, [6] dealt with the phenomenon of structural relaxation of the material after its preliminary thermomechanical treatment.

The stress of the material and its shear rate are important indicators in rheology. These indicators characterize the viscosity and elasticity of the dispersed material (suspensions and emulsions) during the deformation process. Suspensions and emulsions in rheological models should be considered as two-phase systems, while their viscosity is determined. Consideration of the parameters of the machining of the material, such as pressure and force, is crucial to model the rheological characteristics accurately. Otherwise, the assessment of materials' rheological characteristics would be significantly complicated and inaccurate [3].

The deployment of vibration-based technologies is steadily growing to process various materials. The effectiveness of vibration-based processes depends on the construction of the equipment, modes of material processing, and rheological properties. Although the impacts of vibration in the separation of heterogeneous dispersed systems significantly intensify this process, there is a research gap about studying the vibration influence on the rheological characteristics of the material.

A few types of research like have been performed to distinguish the vibration influence on the rheological characteristics of glycerol [8].

The mechanic-rheological methods [3] are widely used to select the optimum technological parameters of material processing based on vibration-based processes. This is mainly because of the simultaneous consideration of the interaction of the machine's mechanical characteristics and the material's rheological characteristics in the mechanic-rheological methods. In this paper, the new mechanic-rheological studies are proposed to identify the effective operating modes of machine introduced in [6], which is useful for glycerin purification based on combinatorial centrifugation and vibration separation processes. Developing mathematical evaluations based on the experimental results is one of the most important contributions of this paper. Test results illustrate the advantages of the proposed method.

The main contribution of this work is the development of a new method for estimating the rheological characteristics of raw glycerin. The compression device is used to perform this method. That allows establishing clearly the characteristic of unilateral deformation of glycerin at various technological modes of processing.

\section{№ 2 (101) \\ 2021 \\ Вібрації в техніці \\ та технологіях}

Compression device is used to find the magnitude and time of deformation of glycerin at different parameters of technological influence. Afterwards, the stress and viscosity of glycerin are calculated from the Kelvin-Voigt equation.

The crude glycerin, as the testing material of this study, is an elastic-viscous medium (nonNewtonian fluid). The Kelvin-Voigt rheological model is usually used to describe the unilateral deformation of such materials, as shown in Fig. 2 [3]. This model consists of Hooke and Maxwell's elements characterizing the elastic and viscous properties of the material, respectively. The mathematical expression of this model could be presented as Eq. (1):

$$
\sigma=E \varepsilon+\eta \varepsilon^{*}
$$

The feasible solutions of Eq. (1) depend on material processing technology. It might have several processing stages. Each processing stage leads to some deformation in the material as a result of mechanical influence on the material. In addition, some deformations would be done during the next technological stages of processing. The stress of the material, including strain and shear rate terms, are very important because in the proposed case, complex vibration and centrifugal technology are used to purify glycerin in this research.

The deployment of this technology combines combining two technological stages highlights the effectiveness of the Kelvin-Voigt rheological model. The glycerin's modulus of elasticity is considered to be 4,35 GPa.

The controlling of vibration settings is an effective means of controlling the dynamic state of the dispersion process. The vibration causes an intense mutual movement of the particles, which sharply increases the speed of each particle relative to their centers of mass. In this case, the properties of the dispersed systems depend on the ratio of the mass of the particles and their acceleration. The magnitude of the coupling force would be much smaller than the value of the vibration impulse. Therefore, it is concluded that the technological parameters of the vibration source have a significant impact on the rheological properties of the material.

Based on the above explanations, it is necessary to modify Eq. (1) to reflect changes in the rheological characteristics of the material accurately. The modified mathematical modeling should represent both centrifugal and vibrational effects on the material.

In this paper, the general mathematical model of deformation of a viscoelastic material, which is developed for the new glycerin purification method.

In this paper, the compression device was used to determine the value of deformation, which characterizes the properties of the material at 


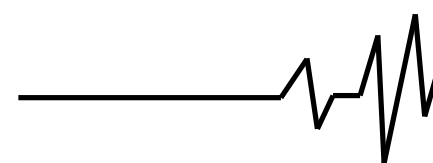

different technological stages. This device has been developed at the National University of Food Technology, Ukraine, as shown in Fig. 2. The compression device consists of a cylindrical body, which its bottom part is fixed on the vibrating plane. A $1 \mathrm{dm}^{3}$ dose of glycerin is loaded inside the cylindrical body, between the pressing and bottom plates. Moreover, the compression chamber has been shaped like a cylinder: $10 \mathrm{~cm}$ diameter and $13 \mathrm{~cm}$ height, while a pressing shaft provides the compression of glycerin.

A measuring microscale has been used to identify the value of the material's deformation during the compression. The temperature of the glycerin has been considered to be $60^{\circ} \mathrm{C}$ based on the data of [3], which is controlled using a heater. The developed construction of the selected compression device is very successful because it could be used to search for materials' rheological coefficients at different processing.

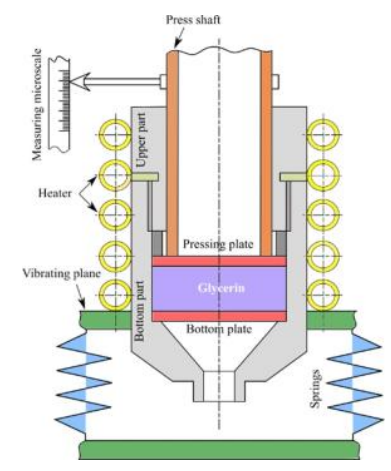

Fig. 2. The compression device for determining the rheological coefficients

In the experimental tests, the vibration frequency sweep from $10 \mathrm{rad} \cdot \mathrm{s}^{-1}$ to $120 \mathrm{rad} \cdot \mathrm{s}^{-1}$ has been applied. In addition, different material's compression forces have been examined. For the centrifugation process, the compression pressure $\left(P_{c}\right)$ is assumed to be about $57 \cdot 10^{3} \mathrm{~Pa}$.

The vibration pressure $\left(P_{v}\right)$ is utilized to estimate the force influence on the material during vibration separation. It should be noted that the vibration pressure is dramatically dependent on the value of the angular speed $(\omega)$ of the vibrating machine. The required vibration pressure $\left(P_{v}\right)$ is generated using the vibration plane of the compression device. Therefore, for further research, it is essential to determine the magnitude of the vibration pressure, particularly based on the designed and implemented experimental set-up.

Firstly, the magnitude of the oscillatory force $\left(F_{v}\right)$ for vibration machine should be determined multiplying the vibration acceleration $\left(a_{z}\right)$ and the total mass of the oscillating part of the vibration machine. Then, the vibration force' value is divided by the size of the area of the vibration separator, and the vibration pressure $\left(P_{v}\right)$ on the glycerin would be determined.

In the proposed approach to determine the rheological coefficients of raw glycerin purification, the duration $(t)$ and the magnitude of deformation $(\varepsilon)$ of the material are determined using the compression device. Then, the deformation's magnitude against the deformation time would be evaluated based on the measured experimental results. Furthermore, different rheological properties of various conditional materials are studies in this paper.

As discussed, it is possible to identify the value of modulus of elasticity $(E)$ as a function of $\sigma$. $E^{-1}$. Afterwards, the value of stress of the material $(\sigma)$ could be calculated using the value of $E$.

Test results infer that the vibration greatly accelerates the value strain of the glycerin. The comparison of test results shows that the maximum value of strain would be $\varepsilon_{v} \approx 1,8 \cdot 10^{-3} \mathrm{~mm} \cdot \mathrm{mm}^{-1}$ at $t=$ $0,15 \mathrm{~s}$ under the vibration-based process, while the maximum value of strain is $\varepsilon_{c} \approx 1,3 \cdot 10^{-3} \mathrm{~mm} \cdot \mathrm{mm}^{-1}$ at the time $t=0,30 \mathrm{~s}$ under centrifugation-based process. The faster and higher strain is achievable by applying the vibration-based process $[9,10]$.

It was assumed that some values can be neglected to calculate the rheological coefficients. The typical calculations of rheological coefficients for raw glycerin purification at the specific parameters $\left(P_{c} \approx 57 \cdot 10^{3} \mathrm{~Pa}\right.$ and $\left.P_{v} \approx 77 \cdot 10^{3} \mathrm{~Pa}\right)$ are presented to clarify how the proposed method could be implemented.

The general characteristics of the rheological coefficients for glycerin under different non-vibration based and vibration-based process are shown in Table 1.

Table 1.

Rheological coefficients for the glycerin at different processing at $P_{c} \approx 57 \cdot 10^{3} \mathrm{~Pa}$ and $P_{v} \approx 77 \cdot 10^{3} \mathrm{~Pa}$

\begin{tabular}{|c|c|c|c|}
\hline \multirow{2}{*}{ No. } & \multirow{2}{*}{ Coefficient } & \multicolumn{2}{|c|}{ Value } \\
\cline { 3 - 4 } & & Centrifugation & Vibration separation \\
\hline 1 & $\eta(\mathrm{Pa} \cdot \mathrm{s})$ & $5.6 \cdot 10^{7}$ & $2.8 \cdot 10^{7}$ \\
\hline 2 & $\sigma(\mathrm{Pa})$ & $5.59 \cdot 10^{6}$ & $7.74 \cdot 10^{6}$ \\
\hline 3 & $E\left(\mathrm{~mm} \cdot \mathrm{mm}^{-1}\right)$ & $1.3 \cdot 10^{-3}$ & $1.8 \cdot 10^{-3}$ \\
\hline 4 & $\lambda\left(\mathrm{s}^{-1}\right)$ & 76 & 153 \\
\hline
\end{tabular}




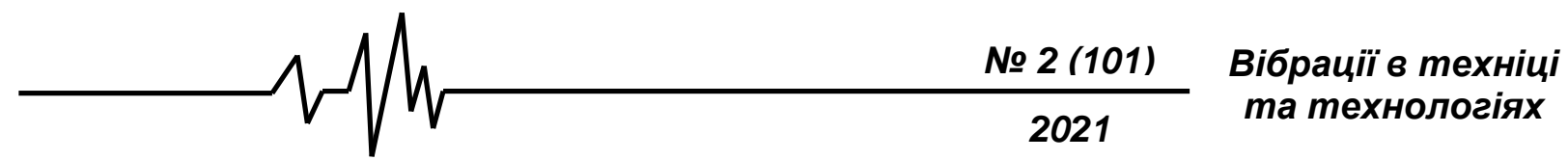

\section{Conclusions.}

The proposed biofuel production line allows to effectively purify by-products, in particular crude glycerin, for further use in the food, pharmaceutical, medical and other fields.

Centrifugal, filtration and vibration action on the liquid technological environment in the developed vibrating machine allows to reduce processing time in 3-5 times in comparison with traditional methods of processing.

In this paper, a new methodology has been proposed to evaluate the rheological characteristics of raw glycerin purification based on the experimental testing. A compression device has been used to determine the value of the unilateral deformation of this material, which allows simulating a condition of a material at various technological modes of processing. In this study, the changes of material properties under centrifugation and vibration separation processes in a vibrocentric machine have been investigated.

\section{References}

1. Kaletnik, H. M., Pryshliak, V. M. (2010). Biopalyvo: efektyvnist yoho vyrobnytstva ta spozhyvannia $\vee$ APK Ukrainy [Biofuels: efficiency of its production and consumption in the agroindustrial complex of Ukraine]. Khai-Tek Pres. Kiev [in Ukrainian].

2. Kaletnik, H. M. (2010). Biopalyvo. Prodovolcha, enerhetychna ta ekolohichna bezpeka Ukrainy [Biofuels. Food, energy and environmental security of Ukraine]. Khai-Tek Pres. Kiev [in Ukrainian].

3. Guts, V., Polievoda, Y., Koval, O. (2011). Vyznachennia strukturno-mekhanichnykh kharakterystyk viazkopruzhnykh dyspersnykh system. [Determination of structural and mechanical characteristics of viscoelastic disperse systems]. Upakovka. Kiev [in Ukrainian].

4. Yanovych, V., Tsurkan, O., Polievoda, Y. (2019). Development of the vibrocentric machine for the production of a basic mixture of homeopathic preparations. UPB Scientific Bulletin, Series D: Mechanical Engineering. Bucharest [in English].

5. Yanovych, V., Polievoda, Y., Duda, D. (2019). Development of a vibrocentric machine for raw glycerin purification. UPB Scientific Bulletin, Series D: Mechanical Engineering. Bucharest [in English].

6. Palamarchuk, I. P., Polievoda, Y. A., Yanovych, V. P. (2011). Obgruntuvannia viazkisnoi kharakterystyky ridkoho dyspersiinoho seredovyshcha $v$ umovakh vibromekhanichnoi dii. [Substantiation of viscosity characteristics of liquid dispersion medium under conditions of vibromechanical action]. Vibratsii $v$ tekhnitsi ta tekhnolohiiakh. Vseukr. nauk. tekhn. zhurnal. Vinnytsia [in Ukrainian].

7. Palamarchuk, I. P., Polievoda, Y. A., Kachur D. V. (2012). Obhruntuvannia konstruktyvnoho osnashchennia dlia ochyshchennia hlitserynu tekhnolohii vyrobnytstva biopalyva. [Substantiation of structural equipment for glycerin purification of biofuel production technology]. Zbirnyk naukovykh prats Vinnytskoho natsionalnoho ahrarnoho universytetu. Seriia: Tekhnichni nauky. Vinnytsia [in Ukrainian].

8. Polievoda, Y. A. (2015). Perspektyvy zastosuvannia vibratsiinykh efektiv $v$ ridkykh tekhnolohichnykh systemakh kharchovykh i pererobnykh vyrobnytstv. [Prospects for the application of vibration effects in liquid technological systems of food and processing industries.]. Zbirnyk naukovykh prats Vinnytskoho natsionalnoho ahrarnoho universytetu. Seriia: Tekhnichni nauky. Vinnytsia [in Ukrainian].

9. Pat. KM 137018 Ukraina. (2019). Mashyna dlia ochyshchennia ridkoi syrovyny [Machine for cleaning liquid raw materials]. Opubl. 10.10.2018. [in Ukrainian].

10. Pat. KM 131818 Ukraina. (2019). Vibrovidtsentrova mashyna dlia ochyshchennia ridkoi syrovyny. [Vibrocentric machine for cleaning liquid raw materials]. Opubl. 25.01.2019. [in Ukrainian].

\section{ПРИМЕНЕНИЕ ВИБРАЦИОННЫХ ЭФФЕКТОВ ПРИ ПРОИЗВОДСТВЕ БИОТОПЛИВА}

Рассмотрен эфффективный способ переработки побочных продуктов производства биотоплива. Увеличение производительности технологической линии достигается внедрением нового вибрационного оборудования для первичной очистки сырого глицерина.

В этом исследовании предлагается новый подход для определения эффрективных режимов работы машины, что может быть исспользовано для очистки глицерина при комбинированном процессе центрифугирования и вибрационном разделении. На основе экспериментальных результатов разработаны математические механико-реологические оценки.

Предложено оценить реологические характеристики очистки сырого глицерина на основе экспериментальных испытаний. Для определения величины односторонней дерормации этого материала было использовано компрессионное устройство, что позволяет моделировать состояние материала при различных технологических режимах обработки. В этом исследовании рассмотрены изменения свойств материала 


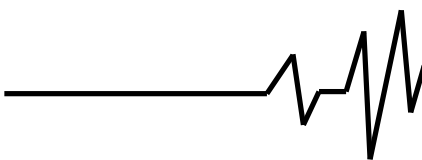

h

.

при прочессах центрифугирования и вибросепарации в исследовательской машине. При выборе оптимальных технологических параметров переработки пищевых масс с помощью вибрационных методов широко применяются методы реологии, в частности взаимодействие рабочего органа машины со средой, которая обрабатывается.

C целью почска оптимальных параметров технологического режима процесс рассматривался комплексно с позиций механики и реологии. Методы механики описывают взаимодействие рабочего органа с обрабатываемой средой, как механическим объектом, реология в свою очередь, позволяет выявить внутренние процессы в самой среде.

Исследуемую систему можно отнести к упруго-вязкой среде, что описывается феноменологической моделью, состоящей из взаимосвязанных упругих и вязких элементов.

Ключевые слова: сырой гличерин, оптимальные параметры, компрессионное устройство, реология, эфорект вибрации, биотопливо, катализатор.

\section{ЗАСТОСУВАННЯ ВІБРАЦІЙНИХ ЕФЕКТІВ ПРИ ВИРОБНИЦТВІ БІОПАЛИВА}

Розглянутий ефективний спосіб переробки побічних продуктів виробництва біопалива. Збільшення продуктивності технологічної лінії досягається впровадженням нового вібраційного обладнання для первинної очистки сирого гліцерину.

У даному дослідженні пропонується новий підхід для визначення ефрективних режимів роботи машини, що може бути використано для очищення гліцерину за комбінованого процесу центрифугування та вібраційного розділення. На основі експериментальних результатів розроблено математичні механіко-реологічні оцінки.

Запропоновано оцінити реологічні характеристики очищення сирого гліцерину на основі експериментальних випробувань. Для визначення величини односторонньої деформації цього матеріалу було використано компресійний пристрій, що дозволяє моделювати стан матеріалу при різних технологічних режимах обробки. У дослідженні розглянуто зміни властивостей матеріалу при процесах центрифугування та вібросепарації у дослідній машині.

$$
\text { При виборі оптимальних }
$$

технологічних параметрів переробки харчових мас за допомогою вібраційних методів широко застосовуються методи реології, зокрема взаємодія робочого органу машини з середовищем, що обробляється.

з метою пошуку оптимальних параметрів технологічного режиму процес розглядався комплексно з позицій механіки та реології. Методи механіки описують взаємодію робочого органу з середовищем, що обробляється, реологія, $y$ свою чергу, дозволяє виявити внутрішні процеси в середовищі.

Досліджувану систему можна віднести до пружно-в'язкого середовища, яке описується феноменологічною моделлю, що складається з взаємопов'язаних пружних та в'язких елементів.

Ключові слова: сирий гліцерин, оптимальні параметри, компресійний пристрій, реологія, ефект вібрації, біопаливо, каталізатор.

\section{Відомості про автора}

Полєвода Юрій Алікович - кандидат технічних наук, доцент кафедри технологічних процесів та обладнання переробних і харчових виробництв Вінницького національного аграрного університету: м. Вінниця, вул. Сонячна 3, 21008, e-mail: vinyura36@gmail.com.

Полевода Юрий Аликович - кандидат технических наук, доцент кафедры технологических процессов и оборудования перерабатывающих и пищевых производств Винницкого национального аграрного университета г. Винница, ул. Солнечная 3, 21008, email: vinyura36@gmail.com.

Polievoda Yurii - candidate of technical sciences, associate professor of the department of technological processes and equipment for processing and food production, Vinnytsia National Agrarian University: Vinnytsia, st. Sonyachna 3, 21008, e-mail: vinyura36@gmail.com. 